\title{
Peptidyl-prolyl cis/trans isomerases in GtoPdb v.2021.2
}

\author{
Stephanie Annett ${ }^{1}$ and Tracy Robson ${ }^{1}$
}

1. RCSI, University of Medicine and Health Sciences, Ireland

\begin{abstract}
Peptidyl-prolyl cis/trans isomerases (PPIases) are an enzyme family which catalyse the cis/trans isomerisation of proline peptide bonds to promote the folding and re-folding of peptides and proteins. Three subfamilies have been identified: cyclophilins, FK506-binding proteins and parvulins. Individual PPIases are overexpressed in a number of cancers [59], and family members have been targetted for immunosuppressant effects.
\end{abstract}

\section{Contents}

This is a citation summary for Peptidyl-prolyl cis/trans isomerases in the Guide to Pharmacology database (GtoPdb). It exists purely as an adjunct to the database to facilitate the recognition of citations to and from the database by citation analyzers. Readers will almost certainly want to visit the relevant sections of the database which are given here under database links.

GtoPdb is an expert-driven guide to pharmacological targets and the substances that act on them. GtoPdb is a reference work which is most usefully represented as an on-line database. As in any publication this work should be appropriately cited, and the papers it cites should also be recognized. This document provides a citation for the relevant parts of the database, and also provides a reference list for the research cited by those parts. For further details see [9].

Please note that the database version for the citations given in GtoPdb are to the most recent preceding version in which the family or its subfamilies and targets were substantially changed. The links below are to the current version. If you need to consult the cited version, rather than the most recent version, please contact the GtoPdb curators.

\section{Database links}

Peptidyl-prolyl cis/trans isomerases

https://www.guidetopharmacology.org/GRAC/FamilyDisplayForward?familyId=845

Introduction to Peptidyl-prolyl cis/trans isomerases

https://www.guidetopharmacology.org/GRAC/FamilyIntroductionForward?familyId=845

Enzymes

FKBP12(FKBP prolyl isomerase 1A)

https://www.guidetopharmacology.org/GRAC/ObjectDisplayForward?objectId=2609 FKBP38(FKBP prolyl isomerase 8)

https://www.guidetopharmacology.org/GRAC/ObjectDisplayForward?objectId=3177 FKBP51(FKBP prolyl isomerase 5)

https://www.guidetopharmacology.org/GRAC/ObjectDisplayForward?objectId=3175 FKBP52(FKBP prolyl isomerase 4)

https://www.guidetopharmacology.org/GRAC/ObjectDisplayForward?objectId=3176 FKBP prolyl isomerase like

https://www.guidetopharmacology.org/GRAC/ObjectDisplayForward?objectId=3178 peptidylprolyl cis/trans isomerase, NIMA-interacting 1

https://www.guidetopharmacology.org/GRAC/ObjectDisplayForward?objectId=3171 Cyclophilin A(peptidylprolyl isomerase A)

https://www.guidetopharmacology.org/GRAC/ObjectDisplayForward?objectId=2751

Cyclophilin D(peptidylprolyl isomerase D)

https://www.guidetopharmacology.org/GRAC/ObjectDisplayForward?objectId=3179 


\section{References}

1. Annett S, Moore G and Robson T. (2020) FK506 binding proteins and inflammation related signalling pathways; basic biology, current status and future prospects for pharmacological intervention. Pharmacol Ther 215: 107623 [PMID:32622856]

2. Annett S, Moore G, Short A, Marshall A, McCrudden C, Yakkundi A, Das S, McCluggage WG, Nelson L and Harley I et al.. (2020) FKBPL-based peptide, ALM201, targets angiogenesis and cancer stem cells in ovarian cancer. Br J Cancer 122: 361-371 [PMID:31772325]

3. Azzolin L, Antolini N, Calderan A, Ruzza P, Sciacovelli M, Marin O, Mammi S, Bernardi P and Rasola A. (2011) Antamanide, a derivative of Amanita phalloides, is a novel inhibitor of the mitochondrial permeability transition pore. PLoS One 6: e16280 [PMID:21297983]

4. Barik S. (2018) Dual-Family Peptidylprolyl Isomerases (Immunophilins) of Select Monocellular Organisms. Biomolecules 8 [PMID:30445770]

5. Biasutto L, Azzolini M, Szabò I and Zoratti M. (2016) The mitochondrial permeability transition pore in AD 2016: An update. Biochim Biophys Acta 1863: 2515-30 [PMID:26902508]

6. Blair LJ, Baker JD, Sabbagh JJ and Dickey CA. (2015) The emerging role of peptidyl-prolyl isomerase chaperones in tau oligomerization, amyloid processing, and Alzheimer's disease. $J$ Neurochem 133: 1-13 [PMID:25628064]

7. Bracher A, Kozany C, Hähle A, Wild P, Zacharias M and Hausch F. (2013) Crystal structures of the free and ligand-bound FK1-FK2 domain segment of FKBP52 reveal a flexible inter-domain hinge. J Mol Biol 425: 4134-44 [PMID:23933011]

8. Briston T, Lewis S, Koglin M, Mistry K, Shen Y, Hartopp N, Katsumata R, Fukumoto H, Duchen MR and Szabadkai G et al.. (2016) Identification of ER-000444793, a Cyclophilin D-independent inhibitor of mitochondrial permeability transition, using a high-throughput screen in cryopreserved mitochondria. Sci Rep 6: 37798 [PMID:27886240]

9. Buneman P, Christie G, Davies JA, Dimitrellou R, Harding SD, Pawson AJ, Sharman JL and Wu Y. (2020) Why data citation isn't working, and what to do about it Database 2020 [PMID:32367113]

10. Butterfield DA, Abdul HM, Opii W, Newman SF, Joshi G, Ansari MA and Sultana R. (2006) Pin1 in Alzheimer's disease. J Neurochem 98: 1697-706 [PMID:16945100]

11. Clarke SJ, McStay GP and Halestrap AP. (2002) Sanglifehrin A acts as a potent inhibitor of the mitochondrial permeability transition and reperfusion injury of the heart by binding to cyclophilin-D at a different site from cyclosporin A. J Biol Chem 277: 34793-9 [PMID:12095984]

12. Donley C, McClelland K, McKeen HD, Nelson L, Yakkundi A, Jithesh PV, Burrows J, McClements L, Valentine A and Prise KM et al.. (2014) Identification of RBCK1 as a novel regulator of FKBPL: implications for tumor growth and response to tamoxifen. Oncogene 33: 3441-50 [PMID:23912458]

13. Dube H, Selwood D, Malouitre S, Capano M, Simone MI and Crompton M. (2012) A mitochondrial-targeted cyclosporin A with high binding affinity for cyclophilin D yields improved cytoprotection of cardiomyocytes. Biochem J 441: 901-7 [PMID:22035570]

14. Dubiella C, Pinch BJ, Koikawa K, Zaidman D, Poon E, Manz TD, Nabet B, He S, Resnick E and Rogel A et al.. (2021) Sulfopin is a covalent inhibitor of Pin1 that blocks Myc-driven tumors in vivo. Nat Chem Biol [PMID:33972797]

15. Dunyak BM and Gestwicki JE. (2016) Peptidyl-Proline Isomerases (PPIases): Targets for Natural Products and Natural Product-Inspired Compounds. J Med Chem 59: 9622-9644 [PMID:27409354]

16. Edlich F, Erdmann F, Jarczowski F, Moutty MC, Weiwad M and Fischer G. (2007) The Bcl-2 regulator FKBP38-calmodulin-Ca2+ is inhibited by Hsp90. J Biol Chem 282: 15341-8 [PMID:17379601]

17. Edlich F and Lücke C. (2011) From cell death to viral replication: the diverse functions of the membrane-associated FKBP38. Curr Opin Pharmacol 11: 348-53 [PMID:21514222]

18. Edlich F, Weiwad M, Wildemann D, Jarczowski F, Kilka S, Moutty MC, Jahreis G, Lücke C, Schmidt W and Striggow F et al.. (2006) The specific FKBP38 inhibitor N-(N',N'dimethylcarboxamidomethyl)cycloheximide has potent neuroprotective and neurotrophic properties in brain ischemia. J Biol Chem 281: 14961-70 [PMID:16547004]

19. Elkamhawy A, Park JE, Hassan AHE, Pae AN, Lee J, Park BG and Roh EJ. (2018) Synthesis and evaluation of 2-(3-arylureido)pyridines and 2-(3-arylureido)pyrazines as potential modulators of A $\beta$-induced mitochondrial dysfunction in Alzheimer's disease. Eur J Med Chem 144: 529-543 [PMID:29288949]

20. Erlejman AG, De Leo SA, Mazaira GI, Molinari AM, Camisay MF, Fontana V, Cox MB, PiwienPilipuk G and Galigniana MD. (2014) NF-kB transcriptional activity is modulated by FK506binding proteins FKBP51 and FKBP52: a role for peptidyl-prolyl isomerase activity. J Biol Chem 289: 26263-26276 [PMID:25104352]

21. Esnault S, Shen ZJ and Malter JS. (2008) Pinning down signaling in the immune system: the role of the peptidyl-prolyl isomerase Pin1 in immune cell function. Crit Rev Immunol 28: 45-60 
[PMID:18298383]

22. Frausto SD, Lee E and Tang H. (2013) Cyclophilins as modulators of viral replication. Viruses 5 : 1684-701 [PMID:23852270]

23. Fruman DA, Klee CB, Bierer BE and Burakoff SJ. (1992) Calcineurin phosphatase activity in T lymphocytes is inhibited by FK 506 and cyclosporin A. Proc Natl Acad Sci USA 89: 3686-90 [PMID:1373887]

24. Gaali S, Kirschner A, Cuboni S, Hartmann J, Kozany C, Balsevich G, Namendorf C, FernandezVizarra P, Sippel C and Zannas AS et al.. (2015) Selective inhibitors of the FK506-binding protein 51 by induced fit. Nat Chem Biol 11: 33-7 [PMID:25436518]

25. Garcia-Touchard A, Burke SE, Toner JL, Cromack K and Schwartz RS. (2006) Zotarolimuseluting stents reduce experimental coronary artery neointimal hyperplasia after 4 weeks. Eur Heart J 27: 988-93 [PMID:16449248]

26. Ghartey-Kwansah G, Li Z, Feng R, Wang L, Zhou X, Chen FZ, Xu MM, Jones O, Mu Y and Chen S et al.. (2018) Comparative analysis of FKBP family protein: evaluation, structure, and function in mammals and Drosophila melanogaster. BMC Dev Biol 18: 7 [PMID:29587629]

27. Girardini JE, Napoli M, Piazza S, Rustighi A, Marotta C, Radaelli E, Capaci V, Jordan L, Quinlan $\mathrm{P}$ and Thompson A et al.. (2011) A Pin1/mutant p53 axis promotes aggressiveness in breast cancer. Cancer Cell 20: 79-91 [PMID:21741598]

28. Gopalakrishnan R, Kozany C, Wang Y, Schneider S, Hoogeland B, Bracher A and Hausch F. (2012) Exploration of pipecolate sulfonamides as binders of the FK506-binding proteins 51 and 52. J Med Chem 55: 4123-31 [PMID:22455398]

29. Guo C, Hou X, Dong L, Marakovits J, Greasley S, Dagostino E, Ferre R, Johnson MC, Humphries PS and Li H et al.. (2014) Structure-based design of novel human Pin1 inhibitors (III): optimizing affinity beyond the phosphate recognition pocket. Bioorg Med Chem Lett 24: 4187-91 [PMID:25091930]

30. Göthel SF and Marahiel MA. (1999) Peptidyl-prolyl cis-trans isomerases, a superfamily of ubiquitous folding catalysts. Cell Mol Life Sci 55: 423-36 [PMID:10228556]

31. Hamilton GS and Steiner JP. (1998) Immunophilins: beyond immunosuppression. J Med Chem 41: 5119-43 [PMID:9857082]

32. Handschumacher RE, Harding MW, Rice J, Drugge RJ and Speicher DW. (1984) Cyclophilin: a specific cytosolic binding protein for cyclosporin A. Science 226: 544-7 [PMID:6238408]

33. Hansson MJ, Mattiasson G, Månsson R, Karlsson J, Keep MF, Waldmeier P, Ruegg UT, Dumont JM, Besseghir K and Elmér E. (2004) The nonimmunosuppressive cyclosporin analogs NIM811 and UNIL025 display nanomolar potencies on permeability transition in brain-derived mitochondria. J Bioenerg Biomembr 36: 407-13 [PMID:15377880]

34. Hultsch T, Müller KD, Meingassner JG, Grassberger M, Schopf RE and Knop J. (1998) Ascomycin macrolactam derivative SDZ ASM 981 inhibits the release of granule-associated mediators and of newly synthesized cytokines in RBL $2 \mathrm{H} 3$ mast cells in an immunophilin-dependent manner. Arch Dermatol Res 290: 501-7 [PMID:9808344]

35. Ji KY, Kim SM, Yee SM, Kim MJ, Ban YJ, Kim EM, Lee EH, Choi HR, Yun H and Lee CW et al.. (2021) Cyclophilin A is an endogenous ligand for the triggering receptor expressed on myeloid cells-2 (TREM2). FASEB J 35: e21479 [PMID:33710680]

36. Khaspekov L, Friberg H, Halestrap A, Viktorov I and Wieloch T. (1999) Cyclosporin A and its nonimmunosuppressive analogue N-Me-Val-4-cyclosporin A mitigate glucose/oxygen deprivation-induced damage to rat cultured hippocampal neurons. Eur J Neurosci 11: 3194-8 [PMID:10510183]

37. Kolos JM, Voll AM, Bauder M and Hausch F. (2018) FKBP Ligands-Where We Are and Where to Go? Front Pharmacol 9: 1425 [PMID:30568592]

38. Koren 3rd J, Jinwal UK, Davey Z, Kiray J, Arulselvam K and Dickey CA. (2011) Bending tau into shape: the emerging role of peptidyl-prolyl isomerases in tauopathies. Mol Neurobiol 44: 65-70 [PMID:21523562]

39. Kuglstatter A, Mueller F, Kusznir E, Gsell B, Stihle M, Thoma R, Benz J, Aspeslet L, Freitag D and Hennig M. (2011) Structural basis for the cyclophilin A binding affinity and immunosuppressive potency of E-ISA247 (voclosporin). Acta Crystallogr D Biol Crystallogr 67: 119-23 [PMID:21245533]

40. Lammers M, Neumann H, Chin JW and James LC. (2010) Acetylation regulates cyclophilin A catalysis, immunosuppression and HIV isomerization. Nat Chem Biol 6: 331-7 [PMID:20364129]

41. Liou YC, Sun A, Ryo A, Zhou XZ, Yu ZX, Huang HK, Uchida T, Bronson R, Bing G and Li X et al.. (2003) Role of the prolyl isomerase Pin1 in protecting against age-dependent neurodegeneration. Nature 424: 556-61 [PMID:12891359]

42. Liu J, Farmer Jr JD, Lane WS, Friedman J, Weissman I and Schreiber SL. (1991) Calcineurin is a common target of cyclophilin-cyclosporin A and FKBP-FK506 complexes. Cell 66: 807-15 [PMID:1715244]

43. Lu KP and Zhou XZ. (2007) The prolyl isomerase PIN1: a pivotal new twist in phosphorylation signalling and disease. Nat Rev Mol Cell Biol 8: 904-16 [PMID:17878917] 
44. Lu PJ, Wulf G, Zhou XZ, Davies P and Lu KP. (1999) The prolyl isomerase Pin1 restores the function of Alzheimer-associated phosphorylated tau protein. Nature 399: 784-8 [PMID:10391244]

45. Luger T, Van Leent EJ, Graeber M, Hedgecock S, Thurston M, Kandra A, Berth-Jones J, Bjerke J, Christophers E and Knop J et al.. (2001) SDZ ASM 981: an emerging safe and effective treatment for atopic dermatitis. Br J Dermatol 144: 788-94 [PMID:11298538]

46. Maestre-Martínez M, Haupt K, Edlich F, Jahreis G, Jarczowski F, Erdmann F, Fischer G and Lücke C. (2010) New structural aspects of FKBP38 activation. Biol Chem 391: 1157-67 [PMID:20707607]

47. Malouitre S, Dube H, Selwood D and Crompton M. (2009) Mitochondrial targeting of cyclosporin A enables selective inhibition of cyclophilin-D and enhanced cytoprotection after glucose and oxygen deprivation. Biochem J 425: 137-48 [PMID:19832699]

48. McClements L, Annett S, Yakkundi A, O'Rourke M, Valentine A, Moustafa N, Alqudah A, Simões BM, Furlong F and Short A et al.. (2019) FKBPL and its peptide derivatives inhibit endocrine therapy resistant cancer stem cells and breast cancer metastasis by downregulating DLL4 and Notch4. BMC Cancer 19: 351 [PMID:30975104]

49. McClements L, Annett S, Yakkundi A and Robson T. (2015) The Role of Peptidyl Prolyl Isomerases in Aging and Vascular Diseases. Curr Mol Pharmacol 9: 165-79 [PMID:25986561]

50. McClements L, Yakkundi A, Papaspyropoulos A, Harrison H, Ablett MP, Jithesh PV, McKeen HD, Bennett R, Donley C and Kissenpfennig A et al.. (2013) Targeting treatment-resistant breast cancer stem cells with FKBPL and its peptide derivative, AD-01, via the CD44 pathway. Clin Cancer Res 19: 3881-93 [PMID:23741069]

51. McKeen HD, McAlpine K, Valentine A, Quinn DJ, McClelland K, Byrne C, O'Rourke M, Young S, Scott CJ and McCarthy HO et al.. (2008) A novel FK506-like binding protein interacts with the glucocorticoid receptor and regulates steroid receptor signaling. Endocrinology 149: 5724-34 [PMID:18669603]

52. Nath R. (2017) Peptidyl-prolyl isomerase (PPIase): an emerging area in tumor biology Cancer Res Front 3: 126-143

53. Nechama M, Kwon J, Wei S, Kyi AT, Welner RS, Ben-Dov IZ, Arredouani MS, Asara JM, Chen CH and Tsai CY et al.. (2018) The IL-33-PIN1-IRAK-M axis is critical for type 2 immunity in IL-33induced allergic airway inflammation. Nat Commun 9: 1603 [PMID:29686383]

54. Oh J and Malter JS. (2013) Pin1-FADD interactions regulate Fas-mediated apoptosis in activated eosinophils. J Immunol 190: 4937-45 [PMID:23606538]

55. Pastorino L, Sun A, Lu PJ, Zhou XZ, Balastik M, Finn G, Wulf G, Lim J, Li SH and Li X et al.. (2006) The prolyl isomerase Pin1 regulates amyloid precursor protein processing and amyloidbeta production. Nature 440: 528-34 [PMID:16554819]

56. Pinch BJ, Doctor ZM, Nabet B, Browne CM, Seo HS, Mohardt ML, Kozono S, Lian X, Manz TD and Chun Y et al.. (2020) Identification of a potent and selective covalent Pin1 inhibitor. Nat Chem Biol 16: 979-987 [PMID:32483379]

57. Porter Jr GA and Beutner G. (2018) Cyclophilin D, Somehow a Master Regulator of Mitochondrial Function. Biomolecules 8 [PMID:30558250]

58. Qiu C, Albayram O, Kondo A, Wang B, Kim N, Arai K, Tsai CY, Bassal MA, Herbert MK and Washida K et al.. (2021) Cis P-tau underlies vascular contribution to cognitive impairment and dementia and can be effectively targeted by immunotherapy in mice Sci Transl Med [PMID:34078745]

59. Rippmann JF, Hobbie S, Daiber C, Guilliard B, Bauer M, Birk J, Nar H, Garin-Chesa P, Rettig WJ and Schnapp A. (2000) Phosphorylation-dependent proline isomerization catalyzed by Pin1 is essential for tumor cell survival and entry into mitosis. Cell Growth Differ 11: 409-16 [PMID:10939594]

60. Robson T and James IF. (2012) The therapeutic and diagnostic potential of FKBPL; a novel anticancer protein. Drug Discov Today 17: 544-8 [PMID:22265918]

61. Saibil H. (2013) Chaperone machines for protein folding, unfolding and disaggregation. Nat Rev Mol Cell Biol 14: 630-42 [PMID:24026055]

62. Shirane M and Nakayama KI. (2003) Inherent calcineurin inhibitor FKBP38 targets Bcl-2 to mitochondria and inhibits apoptosis. Nat Cell Biol 5: 28-37 [PMID:12510191]

63. Shore ER, Awais M, Kershaw NM, Gibson RR, Pandalaneni S, Latawiec D, Wen L, Javed MA, Criddle DN and Berry N et al.. (2016) Small Molecule Inhibitors of Cyclophilin D To Protect Mitochondrial Function as a Potential Treatment for Acute Pancreatitis. J Med Chem 59: 2596611 [PMID:26950392]

64. Stifani S. (2018) The Multiple Roles of Peptidyl Prolyl Isomerases in Brain Cancer. Biomolecules 8: 112 [PMID:30314361]

65. Storer CL, Dickey CA, Galigniana MD, Rein T and Cox MB. (2011) FKBP51 and FKBP52 in signaling and disease. Trends Endocrinol Metab 22: 481-90 [PMID:21889356]

66. Sunnotel O, Hiripi L, Lagan K, McDaid JR, De León JM, Miyagawa Y, Crowe H, Kaluskar S, Ward $\mathrm{M}$ and Scullion C et al.. (2010) Alterations in the steroid hormone receptor co-chaperone FKBPL 
are associated with male infertility: a case-control study. Reprod Biol Endocrinol 8: 22 [PMID:20210997]

67. Theuerkorn M, Fischer G and Schiene-Fischer C. (2011) Prolyl cis/trans isomerase signalling pathways in cancer. Curr Opin Pharmacol 11: 281-7 [PMID:21497135]

68. Valentine A, O'Rourke M, Yakkundi A, Worthington J, Hookham M, Bicknell R, McCarthy HO, McClelland K, McCallum L and Dyer H et al.. (2011) FKBPL and peptide derivatives: novel biological agents that inhibit angiogenesis by a CD44-dependent mechanism. Clin Cancer Res 17: 1044-56 [PMID:21364036]

69. Waldmeier PC, Feldtrauer JJ, Qian T and Lemasters JJ. (2002) Inhibition of the mitochondrial permeability transition by the nonimmunosuppressive cyclosporin derivative NIM811. Mol Pharmacol 62: 22-9 [PMID:12065751]

70. Warne J, Pryce G, Hill JM, Shi X, Lennerås F, Puentes F, Kip M, Hilditch L, Walker P and Simone MI et al.. (2016) Selective Inhibition of the Mitochondrial Permeability Transition Pore Protects against Neurodegeneration in Experimental Multiple Sclerosis. J Biol Chem 291: 4356-73 [PMID:26679998]

71. Wei S, Yoshida N, Finn G, Kozono S, Nechama M, Kyttaris VC, Zhen Zhou X, Tsokos GC and Ping Lu K. (2016) Pin1-Targeted Therapy for Systemic Lupus Erythematosus. Arthritis Rheumatol 68: 2503-13 [PMID:27159270]

72. Yakkundi A, McCallum L, O'Kane A, Dyer H, Worthington J, McKeen HD, McClements L, Elliott C, McCarthy HO and Hirst DG et al.. (2013) The anti-migratory effects of FKBPL and its peptide derivative, AD-01: regulation of CD44 and the cytoskeletal pathway. PLoS One 8: e55075 [PMID:23457460]

73. Yurchenko V, Constant S, Eisenmesser E and Bukrinsky M. (2010) Cyclophilin-CD147 interactions: a new target for anti-inflammatory therapeutics. Clin Exp Immunol 160: 305-17 [PMID:20345978]

74. Zheng H, You H, Zhou XZ, Murray SA, Uchida T, Wulf G, Gu L, Tang X, Lu KP and Xiao ZX. (2002) The prolyl isomerase Pin1 is a regulator of p53 in genotoxic response. Nature 419: 84953 [PMID:12397361]

75. Zuberbier T, Chong SU, Grunow K, Guhl S, Welker P, Grassberger M and Henz BM. (2001) The ascomycin macrolactam pimecrolimus (Elidel, SDZ ASM 981) is a potent inhibitor of mediator release from human dermal mast cells and peripheral blood basophils. J Allergy Clin Immunol 108: 275-80 [PMID:11496246]

76. Šileikytè J and Forte M. (2016) Shutting down the pore: The search for small molecule inhibitors of the mitochondrial permeability transition. Biochim Biophys Acta 1857: 1197-1202 [PMID:26924772] 